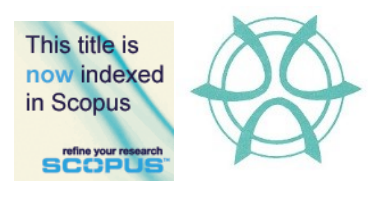

PLANNING MALAYSIA:

Journal of the Malaysian Institute of Planners

VOLUME 19 ISSUE 3 (2021), Page 111 - 122

\title{
AN ANALYSIS ON THE EFFICIENCY OF GREEN ROOF IN MANAGING URBAN STORMWATER RUNOFF
}

\author{
Shazmin Shareena Ab. Azis ${ }^{1}$, Muhammad Najib Bin Mohamed Razali ${ }^{2}$, Nurul \\ Hana Adi Maimun ${ }^{3}$, Nurul Syakima Mohd Yusoff ${ }^{4}$, Mohd Shahril Abdul \\ Rahman $^{5}$, Nur Amira Aina Zulkifli'
}

Real Estate, Faculty of Built Environment and Surveying UNIVERSITI TEKNOLOGI MALAYSIA

\begin{abstract}
Modernization has created new impervious urban landscape contributed to major catastrophe. Urban drainage system incapable to convey the excess rainwater resulting in flash flood due to heavy rainfall. The combination of green roof on building have tremendously proved to control stormwater efficiently. This study is conducted to review the efficiency of intensive and extensive green roof in reducing urban storm water runoff. This study identifies characteristic of green roof that contributes to lessening urban storm water runoff. Data was collected based on rigorous literature reviews and analyzed using meta-analysis. Overall, findings revealed intensive green roof performed better in reducing storm water runoff compared to extensive green roof. Green roof performance increases as the depth of substrate increased. Origanum and Sedum plants are both highly effective for intensive and extensive green roofs. The performance of green roof reduces as degree of roof slope increased.
\end{abstract}

Keywords: Flash flood, urban, green infrastructure, green roof, storm water

\footnotetext{
${ }^{1}$ Senior Lecturer at University Teknologi Malaysia Email: shazmin@utm.my
} 
Shazmin Shareena Ab. Azis, Muhammad Najib Bin Mohamed Razali, Nurul Hana Adi Maimun, Nurul Syakima Mohd Yusoff, Mohd Shahril Abdul Rahman, Nur Amira Aina Zulkifli

An Analysis on The Efficiency of Green Roof in Managing Urban Stormwater Runoff

\section{INTRODUCTION}

New urban landscape surface of densely walled with tall buildings were the effect from changes in economic development, population growth and mitigation from rural to urban areas. This situation may serve as evidence of a mismatch between land supply and brisk population growth in urban areas. Thus, new non-porous or impervious surface has been created in urban landscape. Past research found that conventional roofs consist of $40 \%$ to $50 \%$ of impervious area (Dunnett and Kingsbury, 2004). Countries that received large amount of rainfall every year viewed this new urban landscape as a catastrophic problem.

A non-porous surface creates elevated storm water runoff volumes and flow rates and engulf the existing centralized drainage systems. Storm water runoff created when rain falls on impervious surface and cannot be absorbed into the ground. It makes stream impairment in urban areas which cause by high volumes of water that rapidly transferred to local streams, lakes, wetlands, and rivers which trigger flood phenomena. Report from 2012 till 2016 from Department of Irrigation and Drainage Malaysia reported the major causes of flash flood in the urban area are due to several contributing factors including nonstop heavy rainfall, changes in land uses, and low water infiltration capacity. The impervious surface has changed the hydrological response of natural catchment areas which causes more frequent flooding episodes in the urban region.

Floods are natural disasters that have been affecting human lives ever since the beginning of time. Floods has been recorded among 50\% from all natural disasters that cause deaths around the world (Du et. al., 2010). Tropical climate countries such as Malaysia also suffers this natural disaster which paralyse communities and cause destructions (Elias et. al., 2013). Malaysia has experienced several events of flash floods in the urban area including in Johor Bahru city centre and Kuala Lumpur city centre in 2007 and 2016 respectively. Flash floods were produced when the existing drainage systems does not able to withstand the excess rainwater from an intense burst of rainfall which often cause from thunderstorms.

Hence, there is an urgency to introduced mitigation measures in managing rainwater runoff as response to these disastrous events. Numerous countries have implemented green infrastructure in urban landscape as this solution is designed innovatively to restore environment and ecological damage. Trees and scrubs are found to be vital in avoiding flood disaster as the roots are naturally function as sponge to soak water that falls on the ground (Nagase \& Dunnett, 2012; Razzaghmanesh et. al., 2014).

Scarcity of urban greenery and plantation may be due to the limited vacant land in urban areas. However, green initiatives such as green roof become one of the promising solutions to this issue (Bakar et. al., 2021). The green roof idea was constructed and created to encourage the development of numerous 
types of vegetation on the top of buildings and thus deliver aesthetical, environmental and economic benefits (Vijayaraghavan \& Raja, 2015). Besides, green roof is able to provide annual electricity energy savings by RM139 for residential buildings (Azis et. al., 2019).

Green roofs have been gradually implemented as part of urban stormwater management plans in urban areas. According to Razzaghmanesh and Beecham (2014), the appropriate designed of green roofs can function as storm water source control devices. Henceforth, this study is conducted to review the efficiency of green roof in managing storm water runoff in the urban area. This is conducted through determining the physical characteristics of extensive and intensive green roof that contributes in reducing storm water runoff. The data were collected from literature reviews and analysed using meta-analysis.

\section{GREEN ROOF CONCEPT}

Green roofs are comprised of five components which are water proofing membrane, anti-root sheet, a drainage layer, a filter layer, growth substrate (soil), and vegetation on the top of the structure. Waterproofing sheet is the individual anti-root sheet and placed as a base. The function is to cover the roof by redirecting water to the drainage ducts. Anti-root sheets are placed to avoid harm to the roof waterproofing layers. The drainage layer acts to prevent extreme water stagnation in the substrate that could be harmful to the vegetation. Filter is positioned on top of the layer to prevent parts of the substrate from forming sludge.

Besides, substrate is the layer that strengthens the vegetation and comprises the roots and nutrient materials. The upper layer of the green roof structure is the vegetation or plantation. This layer consists of resistant and aesthetically pleasing vegetation. The most planted varieties on green roofs are succulent's plants such as Sedum. Succulents' plants are best for endurance in green roof systems due to its characteristics of shallow root system and conservative water use strategy (VanWoert et al., 2005; Getter and Rowe, 2009).

\section{Extensive green roof}

Extensive green roofs typically have thin media and drought tolerant vegetation (Berndtsson, 2010; Getter et. al., 2006). Substrate depth of extensive green roof is constructed less than $150 \mathrm{~mm}$ and can be installed on sloped roofs as high as 45 degrees (Renato and Sara, 2016; DeNardo et al., 2005; Mentens et al., 2006; Moran et al., 2003). This type of green roof does not require a complicated construction process (Sajedeh et al., 2015). These roofs are sown with smaller plants such as sedum species which able to provide full coverage of the vegetated roof. 
Shazmin Shareena Ab. Azis, Muhammad Najib Bin Mohamed Razali, Nurul Hana Adi Maimun, Nurul Syakima Mohd Yusoff, Mohd Shahril Abdul Rahman, Nur Amira Aina Zulkifli

An Analysis on The Efficiency of Green Roof in Managing Urban Stormwater Runoff

\section{Intensive green roof}

An intensive green roof is a roof assigned with a substrate layer with a depth of more than $150 \mathrm{~mm}$ and have thicker substrates which may include trees, shrubs, and grasses (Sajedah et al., 2015; Kosareo \& Ries, 2007; Mentens et al., 2007; Carter and Fowler, 2008; Getter and Rowe, 2006). Normally, this type of intensive green roof is set up when the on slope that is less than 10 degree as it can support multiple type of plant but need extra structural reinforcement (Mentens et al., 2003; Sajedah et al., 2015).

Table 1: Comparison of extensive and intensive green roof characteristic

\begin{tabular}{|c|c|c|c|}
\hline \multirow{2}{*}{\multicolumn{2}{|c|}{ Green roof characteristic }} & \multicolumn{2}{|c|}{ Type of green roof } \\
\hline & & Extensive & Intensive \\
\hline \multirow[t]{4}{*}{ Physical } & $\begin{array}{l}\text { Thickness of } \\
\text { growing media }\end{array}$ & Less than $150 \mathrm{~mm}$ & More than $150 \mathrm{~mm}$ \\
\hline & $\begin{array}{l}\text { Type of } \\
\text { vegetation }\end{array}$ & $\begin{array}{l}\text { Combination of large } \\
\text { plant and small plants } \\
\text { e.g.: tress and shrub }\end{array}$ & $\begin{array}{c}\text { Small plant } \\
\text { e.g.: sedum, mosses, } \\
\text { grass }\end{array}$ \\
\hline & Roof slope & Up to 45 degree & Less than 10 degree \\
\hline & Weight & Lightweight & Heavyweight \\
\hline \multirow[t]{4}{*}{ Management } & $\begin{array}{l}\text { Accessibility to } \\
\text { roof top }\end{array}$ & Inaccessible & $\begin{array}{c}\text { Accessible for } \\
\text { recreational activities }\end{array}$ \\
\hline & Cost & low & high \\
\hline & Construction & Moderately easy & Technically complex \\
\hline & Maintenance & Simple & complicated \\
\hline
\end{tabular}

\section{HYDROLOGICAL PROCESS OF SLOWING STORM WATER RUNOFF BY GREEN ROOF}

A green roof manages storm water runoff by reducing and prolonging the peak of water runoff process. Rainfall from asphalt and gravel rooftops produce $62 \%$ to $91 \%$ runoff (Voyde et al., 2010; Razzaghmanesh \& Beecham, 2014). Green roof will detain certain water volume. Retained water will then either evaporate or be transpired by plants which dries out the substrate and regenerates retention capacity before the next rainfall event (Berretta et al., 2014; Poë et al., 2015). Figure 2 below explains the hydrological process of green roof. 


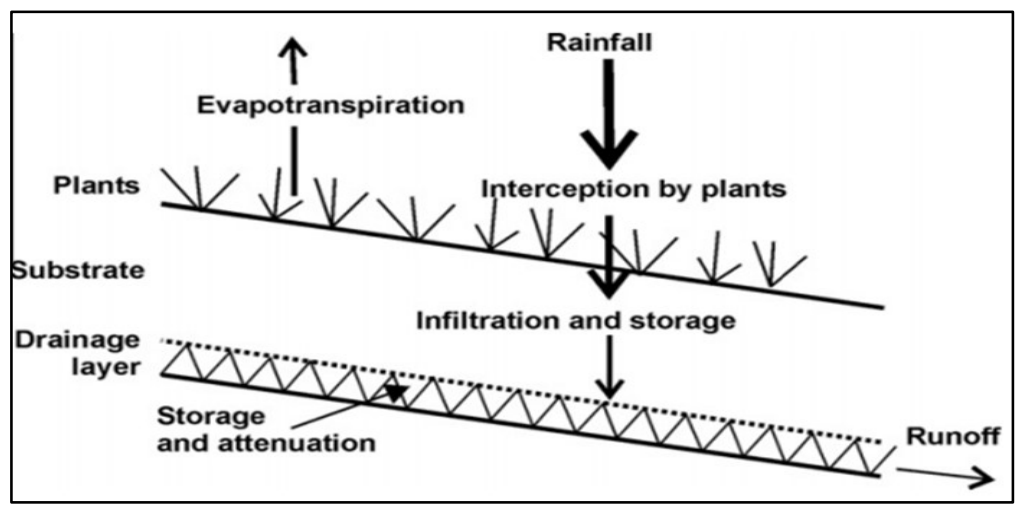

Figure 2: Green roof hydrological process Source: Virginia et al. (2012)

\section{EFFICIENCY OF GREEN ROOF IN REDUCING URBAN STORMWATER RUNOFF}

There are two factors that control green roof water retention capacity and runoff volume which are green roof characteristics and weather conditions (Berndtsson, 2010). In general, green roof capable to lessen storm water runoff roughly $20 \%$ to $90 \%$ varying on type of green roof. The essential green roof characteristics that contributed to reducing storm water runoff are substrates depth, type of vegetation, and roof slope (Liu et al., 2019; Renato \& Sara, 2016; Sajedeh et al., 2015; VanWoert et al., 2005; Getter et al., 2007). This study focuses on intensive and extensive green roof characteristics that influence water retention thus reduce storm water runoff accordingly.

\section{EXTENSIVE GREEN ROOF}

\section{Substrate's depth}

Numerous of studies have been conducted regarding the performance of substrate depth for water runoff retention purposes. A latest green roof study was conducted by Liu et al. (2019) at Gansu province, China. The experiment was conducted on extensive green roof with $150 \mathrm{~mm}$ of substrate depth. The finding indicated that substrate depth contributes to $26.2 \%$ of rainwater retention. Razzaghmanesh and Beecham (2015) has constructed a scale model of extensive green roof at Adelaide, University of South Australia. The findings proved that at $100 \mathrm{~mm}$ of substrate depth, green roof able to reduce $66 \%$ to $81 \%$ of storm water runoff. Overall, substrate depth between $5 \mathrm{~cm}$ and $15 \mathrm{~cm}$ can effectively reduce water runoff at approximately $23 \%-81 \%$. This indicated that deeper subtract depth provide higher storm water reduction. 
Shazmin Shareena Ab. Azis, Muhammad Najib Bin Mohamed Razali, Nurul Hana Adi Maimun, Nurul Syakima Mohd Yusoff, Mohd Shahril Abdul Rahman, Nur Amira Aina Zulkifli

An Analysis on The Efficiency of Green Roof in Managing Urban Stormwater Runoff

\section{Type of vegetation}

Extensive green roof normally sown with smaller plants to provide comprehensive coverage of the vegetated roof (Berndsston, 2010). There are various types of vegetation for extensive green roof including sedum, vegetable, mosses, and centipede grass. Overall, these plantations able to provide $30 \%$ to $89 \%$ reduction of storm water runoff. According to a study by Whittinghill et al. (2015), the most effective type of plant for extensive green roof is Sedum plant.

\section{Roof slope}

Roof slopes affect the effectiveness of green roof in lessening storm water runoff. According to Getter et al. (2007), extensive green roof slope at 25 degrees able to retain water at $75 \%$. Meanwhile at 2 degree of roof slope, it able to produce larger water retention at $85 \%$. Overall, elevated degree of roof slope can decrease green roof performance in reducing storm water runoff.

\section{INTENSIVE GREEN ROOF}

\section{Substrate's depth}

Intensive green roof with deep substrate capable to deliver $60 \%$ of water retention (Viola et al., 2017). Simulation research on intensive green roof by Renato and Sara (2016) shows that intensive green roof able to reduce storm water runoff at $29 \%, 33 \%, 40 \%$, and $54 \%$ at $200 \mathrm{~mm}, 400 \mathrm{~mm}, 800 \mathrm{~mm}$, and $1600 \mathrm{~mm}$ of substrate depth, respectively. Mentens et al. (2006) has proved in his study that intensive green roof with $155 \mathrm{~mm}$ substrate depth contributes to $65 \%$ to $85 \%$ of water retention performance. Overall, substrate depth between $155 \mathrm{~mm}$ and $1600 \mathrm{~mm}$ can effectively reduce water runoff at approximately $29 \%-92 \%$. This result has proved that the deeper the substrate, the higher the water retention performance.

\section{Type of vegetation}

Size and structure of plants significantly influenced the amount of water runoff. Plant species with taller height, larger diameter, and larger shoot and root were more effective in reducing water runoff than plant species with shorter height, smaller diameter, and smaller shoot and root biomass (Nagasea and Dunnett, 2012). It was found that Origanum (tall plant) able to reduce higher storm water runoff that sedum (short plant). Origanum and sedum plant are able to reduce storm water runoff at $79 \%$ and $76 \%$ respectively.

\section{Roof slope}

Roof slopes influence the effectiveness of intensive green roof. According to VanWoert et al. (2005), intensive green roof slope at 6.5 degree can retain $66 \%$ water runoff while at 2 degrees, it retains water at $87 \%$. Overall, higher degree of roof slope reduces the performance of intensive green roof in reducing storm 
water runoff. The summary of extensive and intensive green roof performance is tabulated in Table 1 below.

Table 1: Extensive and Intensive green roof performance in storm water runoff reduction

\begin{tabular}{|c|c|c|c|}
\hline \multirow{2}{*}{$\begin{array}{c}\text { Green } \\
\text { roof } \\
\text { Attributes }\end{array}$} & \multicolumn{2}{|c|}{$\begin{array}{l}\text { Percentages of storm water runoff reduction } \\
\qquad(\%)\end{array}$} & \multirow[t]{2}{*}{ Authors } \\
\hline & Intensive & Extensive & \\
\hline \multirow[t]{7}{*}{$\begin{array}{l}\text { Substrate } \\
\text { depth }\end{array}$} & $\begin{array}{l}29 \%(200 \mathrm{~mm}) \\
33 \%(400 \mathrm{~mm}) \\
40 \%(800 \mathrm{~mm}) \\
54 \%(1600 \mathrm{~mm})\end{array}$ & $\begin{array}{l}26 \%(50 \mathrm{~mm}) \\
27 \%(100 \mathrm{~mm})\end{array}$ & $\begin{array}{l}\text { Renato and Sara } \\
(2016)\end{array}$ \\
\hline & $65 \%-85 \%(155 \mathrm{~mm})$ & $27 \%-81 \%(100 \mathrm{~mm})$ & Mentens et al. (2006) \\
\hline & $85 \%-92 \%(300 \mathrm{~mm})$ & $66 \%-81 \%(100 \mathrm{~mm})$ & $\begin{array}{l}\text { Razzaghmanesh and } \\
\text { Beecham (2015) }\end{array}$ \\
\hline & $85 \%$ & $60 \%$ & Sajedeh et al., (2015) \\
\hline & $65.7 \%(170 \mathrm{~mm})$ & - & Speak et al. (2013) \\
\hline & $60 \%$ & $53 \%$ & Viola et al. (2017) \\
\hline & - & $45 \%-60 \%(150 \mathrm{~mm})$ & $\begin{array}{l}\text { DeNardo et } \\
\text { al.(2005); Mentens et } \\
\text { al. (2006); Moran et } \\
\text { al.(2003) }\end{array}$ \\
\hline \multirow[t]{4}{*}{$\begin{array}{c}\text { Type of } \\
\text { vegetation }\end{array}$} & $\begin{array}{l}77 \% \text { (sedum) } \\
79 \% \text { (origanum) }\end{array}$ & $\begin{array}{l}70 \%(\text { sedum }) \\
71 \% \text { (origanum) }\end{array}$ & $\begin{array}{l}\text { Konstantinos et } \\
\text { al.(2017) }\end{array}$ \\
\hline & - & $66 \%$ (sedum) & Rowe et al. (2003) \\
\hline & - & $\begin{array}{c}47.4 \% \\
\text { (centipedegrass) }\end{array}$ & Shuai et al. (2019) \\
\hline & - & $\begin{array}{c}89 \% \text { (sedum) } \\
35 \%-88 \% \\
\text { (Vegetable) }\end{array}$ & Leigh et al.(2015) \\
\hline \multirow[t]{3}{*}{ Roof slope } & $\begin{array}{c}87 \%(2 \text { degree }) \\
65.9 \%(6.5 \text { degree })\end{array}$ & - & $\begin{array}{l}\text { VanWoert et al. } \\
(2005)\end{array}$ \\
\hline & - & $\begin{array}{l}85.2 \% \text { ( } 2 \text { degree }) \\
75.3 \% \text { ( } 25 \text { degree })\end{array}$ & Getter et al. (2007) \\
\hline & - & $\begin{array}{l}28 \%(2 \text { degree }) \\
25.8 \% \text { (12 degree })\end{array}$ & Wen et al. (2019) \\
\hline
\end{tabular}

\section{COMPARISON BETWEEN INTENSIVE AND EXTENSIVE GREEN ROOF PERFORMANCE FOR STORM WATER RUNOFF REDUCTION}

Figure 3 and Figure 4 illustrate the performance of intensive and extensive green roof in reducing storm water runoff. Both figures have proved there are positive relationship between performance of green roof in reducing storm water runoff 
Shazmin Shareena Ab. Azis, Muhammad Najib Bin Mohamed Razali, Nurul Hana Adi Maimun, Nurul Syakima Mohd Yusoff, Mohd Shahril Abdul Rahman, Nur Amira Aina Zulkifli

An Analysis on The Efficiency of Green Roof in Managing Urban Stormwater Runoff

and depth of substrate. Overall, intensive green roof provides higher percentages of storm water runoff at $54 \%$ compared to extensive green roof at $45 \%$.

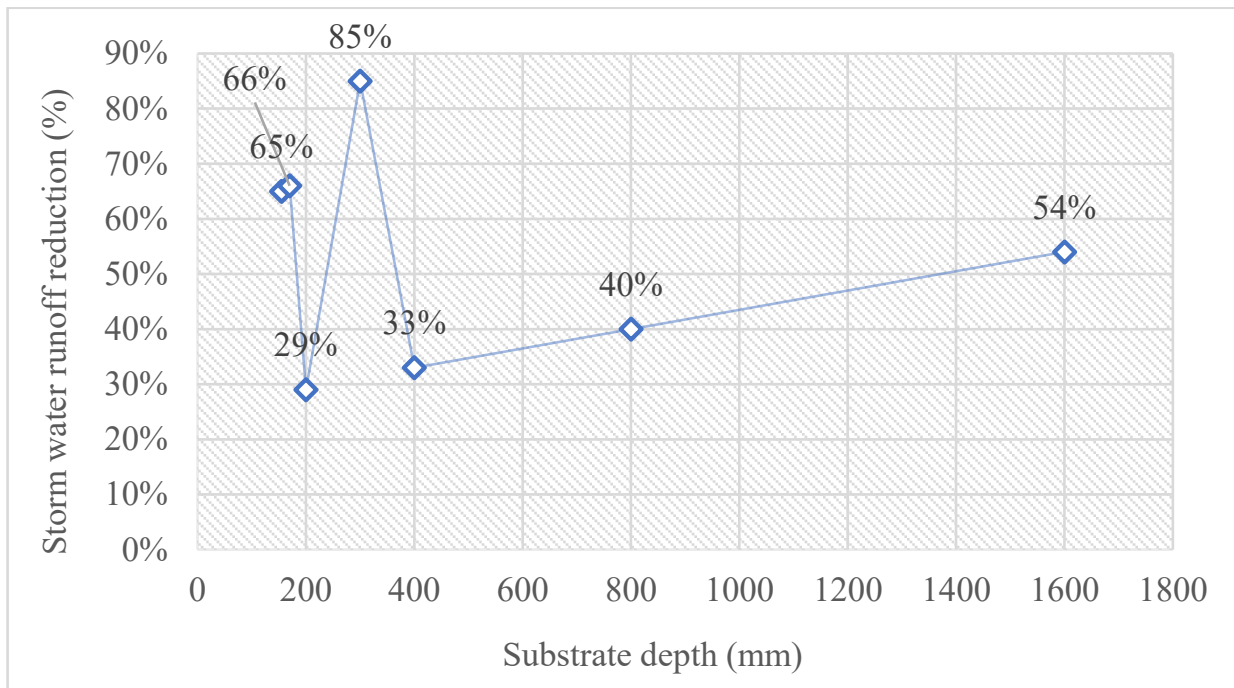

Figure 3: Performance of Intensive green roof based on substrate depth

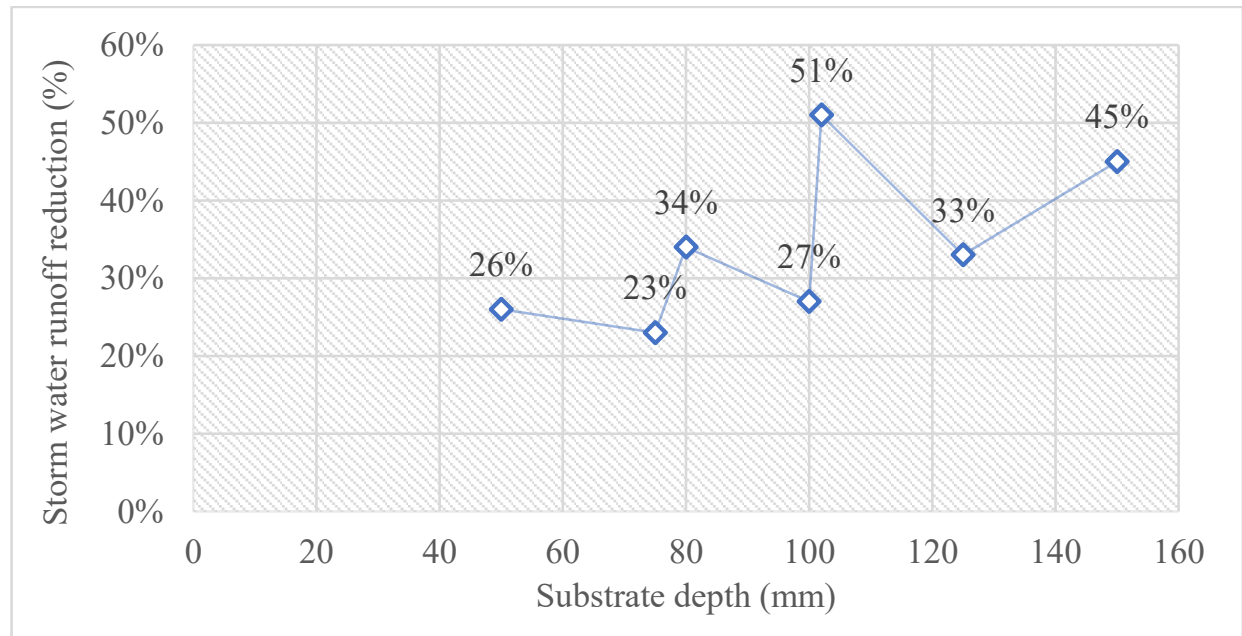

Figure 4: Performance of Extensive green roof based on substrate depth

Meanwhile, Figure 5 and Figure 6 illustrate the performance of both green roof based on type of vegetation. The result shows that for intensive green roof, Origanum plant provides slightly better storm water runoff reduction at $79 \%$ compared to Sedum at $76 \%$. This highlighted that tall plant is more effective to 
be used for intensive green roof. The result is also similar for extensive green roof where origanum and sedum provides highest storm water reduction at $71 \%$ and $66 \%$ respectively. This indicated that origanum plant and sedum plant are the best efficient type of vegetation for intensive and extensive green roof for storm water reduction purposes. Specifically, origanum plant and sedum plant are the most effective under intensive green roof structure than extensive green roof structure.

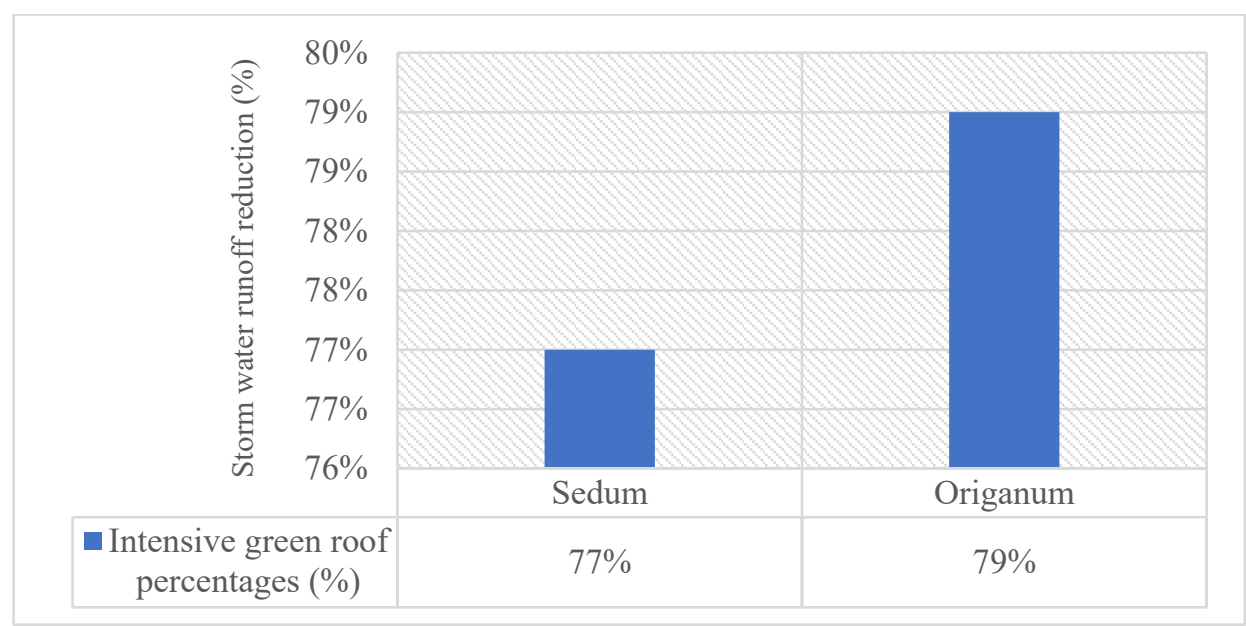

Figure 5: Performance of Intensive green roof based on type of vegetation

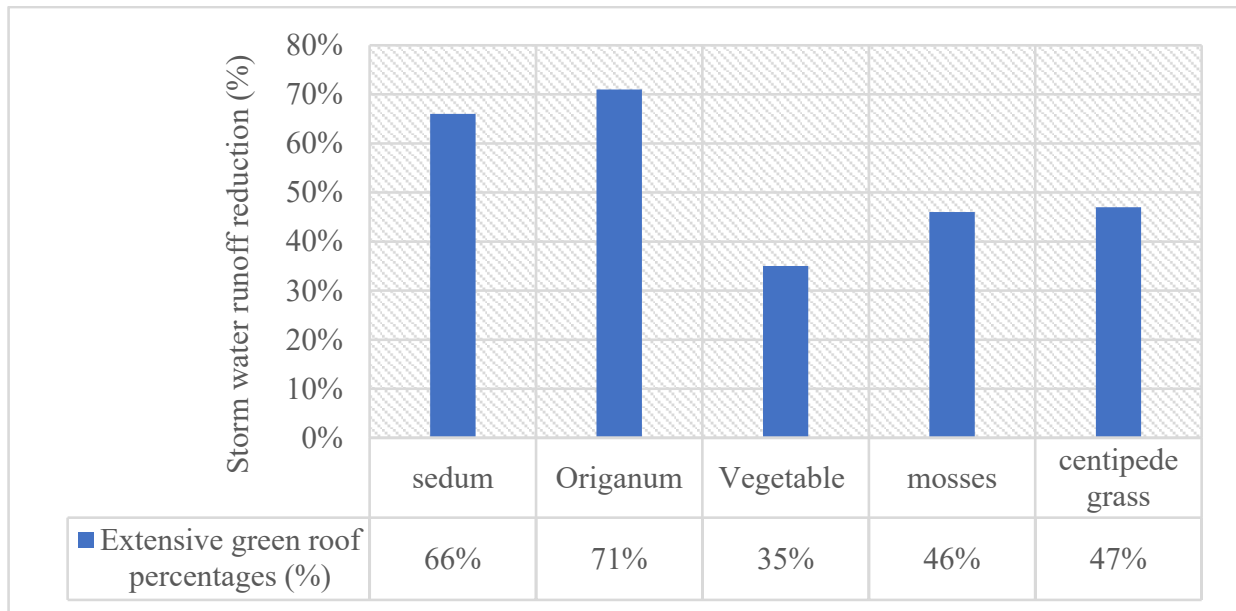

Figure 6: Performance of Extensive green roof based on type of vegetation

Figure 7 illustrates the performance of intensive and extensive green roof according to the degree of roof slope. The result indicated that higher degree of roof slope reduces the performance of green roof in reducing storm water runoff. 
Shazmin Shareena Ab. Azis, Muhammad Najib Bin Mohamed Razali, Nurul Hana Adi Maimun, Nurul Syakima Mohd Yusoff, Mohd Shahril Abdul Rahman, Nur Amira Aina Zulkifli

An Analysis on The Efficiency of Green Roof in Managing Urban Stormwater Runoff

For intensive and extensive green roof, roof slope at 2 degree provides higher storm water runoff reduction at $87 \%$ and $85 \%$ compared to roof slope at 6.5 degree and 25 degrees. Higher roof slope reduces the performance of intensive and extensive green roof. Overall, to achieve highest performance of intensive and extensive green roof, the degree of roof slope must be reduced to minimum degree.

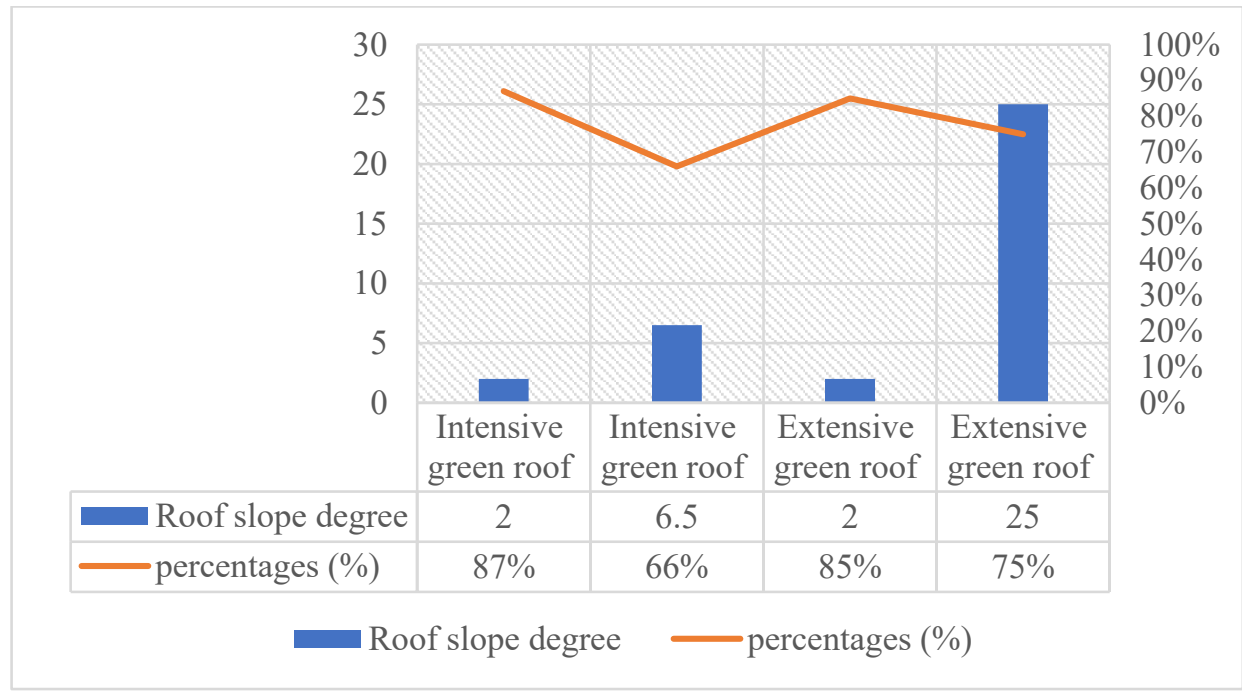

Figure 7: Performance of Intensive and Extensive green roof based on roof slope

\section{CONCLUSIONS}

To conclude, green roof is an effective and environmentally friendly strategies to manage flash flood in urban area though reducing volume of storm water runoff. Generally, intensive green roof performed better in reducing storm water runoff than extensive green roof. There are several attributes of green roof that influences the performance in reducing storm water runoff including substrate depth, type of vegetation, and degree of roof slope. The performance of green roof has positive relationship with depth of substrate. Deeper substrates increase the percentages of storm water runoff reduction. Meanwhile, the performance of green roof has negative relationship with degree of roof slope. Higher degree of roof slope decreases the performance of green roof in reducing storm water runoff. This study is significant mechanism to strategies for urban flash flood control by the government and other relevant parties. 
PLANNING MALAYSIA

Journal of the Malaysia Institute of Planners (2021)

\section{ACKNOWLEDGEMENTS}

The authors would like to thank the Fundamental Research Grant Scheme (FRGS) for funding this study with cost center number: R.J130000.7852.5F201 and project reference number: PY/2019/01198.

\section{REFERENCES}

Azis, S. S. A., Sipan, I., Sapri, M., Yusoff, N. S. M., \& Hashim, H. A. (2019). COMPARISON ON ENERGY SAVING: GREEN ROOF AND GREEN WALL. PLANNING MALAYSIA, 17(9).

Bakar, A. A., Mustapa, S. I., \& Mohammad, N. (2021). GREEN CITY INITIATIVES: HUMAN-NATURE INTERACTION. PLANNING MALAYSIA, 19(15).

Berndtsson, J.C. (2010). Green roof performance towards management of runoff water quantity and quality: a review. Ecol. Eng. 36 (4), 351-360.

Berretta, C., Po€e, S., Stovin, V. (2014). Moisture content behaviour in extensive green roofs during dry periods: the influence of vegetation and substrate characteristics. J. Hydrol. 511, 374e 386 .

Carter, T., \& Jackson, C. R. (2007). Vegetated roofs for stormwater management at multiple special scales. Landscape and Urban Planning, 80, 84-94.

Carter, T.L., Rasmussen, T.C., (2006). Hydrologic behavior of vegetated roofs. Journal of the American Water Resources Association 42 (5), 1261-1274.

DeNardo, J.C., Jarrett, A.R., Manbeck, H.B., Beattie, D.J., Berghage, R.D. (2005). Stormwater mitigation and surface temperature reduction by green roofs. Transactions of the American Society of Agricultural Engineers 48 (4), 14911496.

Getter, K. L., Rowe, D. B., \& Andresen, J. A. (2007). Quantifying the effect of slope on extensive green roof stormwater retention. Ecological Engineering, 31(4), 225231.

Kosareo, L., Ries, R., 2007. Comparative environmental life cycle assessment of green roofs. Build. Environ. 42, 2606-2613.

Liu, K., Minor, J., 2005. Performance Evaluation of an Extensive Green Roof. Greening Rooftops for Sustainable Communities Conference, Washington DC, 4-6 May.

M. Razzaghmanesh and S. Beecham (2014). The hydrological behaviour of extensive and intensive green roofs in a dry climate. Science of the Total Environment 499 (2014) 284-296.

Mentens J, Raes D, Hermy M. (2003). Effect of Orientation on the Water Balance of Green Roofs. Greening rooftops for Sustainable Communities Chicago; 2003. p. 36371.

Mentens, J., Raes, D., Hermy, M., (2006). Green roofs as a tool for solving the rainwaterrunoff problem in the urbanized 21st century? Landscape and Urban Planning 77 (3), 217-226.

Moran A, Hunt B, Jennings G. A North Carolina field study to evaluate greenroof runoff quality, runoff quantity, and plant growth (2003). ASAEPaper 032303Am. Soc. of Agric. Eng.; 2003 
Shazmin Shareena Ab. Azis, Muhammad Najib Bin Mohamed Razali, Nurul Hana Adi Maimun, Nurul Syakima Mohd Yusoff, Mohd Shahril Abdul Rahman, Nur Amira Aina Zulkifli

An Analysis on The Efficiency of Green Roof in Managing Urban Stormwater Runoff

Nagase, A., Dunnett, N. (2012). Amount of water runoff from different vegetation types on extensive green roofs: effects of plant species, diversity and plant structure. Landsc. Urban Plan. 104 (3-4), 356-363.

Poe, S., Stovin, V., Berretta, C. (2015). Parameters influencing the regeneration of a green roof's retention capacity via evapotranspiration. J. Hydrol. 523, 356e367.

Razzaghmanesh M, Beecham S, Kazemi F. (2014). The Growth and Survival of Plants in Urban Green Roofs in a Dry Climate. Sci Total Environ 2014a; 476-477:288-97.

Renato Castiglia Feitosa and Sara Wilkinson (2016). Modelling green roof stormwater response for different soil depths. Landscape and Urban Planning 153 (2016) 170-179.

Speak, A.F., Rothwell, J.J., Lindley, S.J., Smith, C.L. (2013). Rainwater runoff retention on an aged intensive green roof. Sci. Total Environ. 461, 28-38.

Stovin V, Vesuviano G, Kasmin H. (2012). The hydrological performance of a green roof test bed under UK climatic conditions. J Hydrol 2012; 414-415:148-61.

VanWoert N, Rowe B, Andresen J, Rugh C, Fernandez T, Xiao L. (2005). Green roof stormwater retention: effects of roof surface, slope, andmedia depth. J Environ Qual 2005; 34:1036-44.

VanWoert, N.D., Rowe, D.B., Andresen, J.A., Rugh, C.L., Xiao, L. (2005). Watering regime and green roof substrate design affect sedum plant growth. HortScience 40 (3), 659-664.

Vijayaraghavan, K., \& Raja, F. D. (2015). Pilot-scale evaluation of green roofs with Sargassum biomass as an additive to improve runoff quality. Ecological Engineering, 75, 70-78.

Voyde E, Fassman E, Simcock R. (2010). Hydrology of an extensive living roof under sub-tropical climate conditions in Auckland, New Zealand. J Hdrol 2010; 394:384-95.

Dunnett, N., Kircher, W., \& Kingsbury, N. (2004). Communicating naturalistic plantings: plans and specifications. The Dynamic Landscape: Design, Ecology and Management of Naturalistic Urban Planting, 348-368.

Du, W., FitzGerald, G. J., Clark, M., \& Hou, X. Y. (2010). Health impacts of floods. Prehospital and disaster medicine, 25(3), 265-272.

Elias, Z., Hamin, Z., \& Othman, M. B. (2013). Sustainable management of flood risks in Malaysia: Some lessons from the legislation in England and Wales. ProcediaSocial and Behavioral Sciences, 105, 491-497.

Liu, W., Wei, W., Chen, W., Deo, R. C., Si, J., Xi, H., ... \& Feng, Q. (2019). The impacts of substrate and vegetation on stormwater runoff quality from extensive green roofs. Journal of Hydrology, 576, 575-582.

Whittinghill, L. J., Rowe, D. B., Andresen, J. A., \& Cregg, B. M. (2015). Comparison of stormwater runoff from sedum, native prairie, and vegetable producing green roofs. Urban ecosystems, 18(1), 13-29.

Viola, F., Hellies, M., \& Deidda, R. (2017). Retention performance of green roofs in representative climates worldwide. Journal of Hydrology, 553, 763-772.

Received: $12^{\text {th }}$ July 2021. Accepted: $23^{\text {rd }}$ Sept 2021 